\title{
Inwestycje budowlane na gruntach rolnych położonych w granicach administracyjnych miast
}

Działalność inwestycyjna na gruntach rolnych podlegała i podlega szczególnej reglamentacji prawnej.

Poczynając od uregulowań ustawy z dnia 26 października 1971 roku o ochronie gruntów rolnych i leśnych oraz rekultywacji gruntów ${ }^{2}$, poprzez kolejne regulacje: ustawę z 26 marca 1982 roku o ochronie gruntów rolnych i leśnych ${ }^{3}$ oraz obecnie obowiązującą ustawę o tym samym tytule z 3 lutego 1995 roku$^{4}$, ochrona gruntów rolnych jest przedmiotem szczególnej troski ustawodawcy. Jak słusznie podkreśla się w doktrynie, jednym z negatywnych skutków procesów urbanizacji jest zagrożenie dla gruntów rolnych jako szczególnego środka produkcji ${ }^{5}$. Niepomnażalność i nieprzenaszalność gruntów rolnych, w połączeniu z ich wyjątkowymi cechami fizykochemicznymi oraz zachodzącymi w nich procesami biologicznymi, które warunkują ich walor produkcyjny, skłoniła ustawodawcę do wyznaczania racjonalnych kierunków ich wykorzystywania i ochrony.

Jak wiadomo, współczesna regulacja odnosząca się do ochrony gruntów rolnych jako środka produkcji ${ }^{6}$ wyznacza dwa główne kierunki działań:

- ochronę ilościową - w ramach której wprowadzono ograniczenia przeznaczania gruntów rolnych na cele nierolnicze i nieleśne, oraz

- ochronę jakościową - polegającą przede wszystkim na zapobieganiu procesom degradacji i dewastacji gruntów rolnych.

Uniwersytet Warszawski.

Dz.U. Nr 27, poz. 249 z późn. zm.

Dz.U. Nr 11, poz. 79 z późn. zm.

Dz.U. Nr 16, poz. 78 z późn. zm.

T. Kurowska, Prawo rolne, A. Stelmachowski, (red.), Warszawa 2009, s. 590.

Grunty rolne są także przedmiotem ochrony w innych aspektach - np. jako element środowiska - w ramach przepisów o ochronie powierzchni ziemi zawartych w Dziale IV tytułu II ustawy z 27 kwietnia 2001 r. Prawo ochrony środowiska (tekst jedn. Dz.U. z 2008 r. nr 25, poz. 150 z późn. zm.). 
Z punktu widzenia problematyki inwestycji budowlanych na gruntach rolnych zasadnicze znaczenie mają przede wszystkim regulacje odnoszące się do ochrony ilościowej. Podstawowe środki ochrony gruntów rolnych w tym aspekcie to:

1) określenie rodzajów gruntów podlegających ochronie,

2) ustalenie kolejności przekazywania gruntów rolnych na cele nierolnicze,

3) określenie warunków i trybu przeznaczania gruntu rolnego na cele nierolnicze oraz ustalenie kompetencji organów w tym zakresie,

4) nałożenie obowiązku uiszczania należności i opłat rocznych z tytułu wyłączenia z produkcji gruntów rolnych przeznaczonych na cele nierolnicze,

5) kontrola wykorzystania gruntów rolnych na cele nierolnicze.

Przyjęty model ochrony gruntów rolnych, w ramach którego główny akcent kładziony jest na tzw. ochronę ilościową, polegającą na ograniczaniu ich przeznaczania na cele nierolnicze lub nieleśne, musi prowadzić do kolizji pomiędzy celem ustawy a dążeniami właścicieli nieruchomości i inwestorów, którzy pragną maksymalizować wartość nieruchomości przez tworzenie możliwości jej zagospodarowania optymalnego z punktu widzenia ich interesów majątkowych. Kolizje te występują w szczególnym nasileniu na terenach miejskich, na których uwarunkowania ekonomiczne i społeczne tworzą szczególną presję urbanizacyjną. Zgodzić się należy z opiniami, że współczesna ochrona gruntów rolnych winna być ciągiem powiązanych z sobą działań ochronnych i planistycznych, w tym urządzeniowo-rolnych ${ }^{7}$. Jednocześnie, w odniesieniu do gruntów miejskich aspekt ochronny nie powinien dominować nad potrzebami tworzenia i porządkowania przestrzeni inwestycyjnej obejmującej w szczególności tereny aktywności gospodarczej, tereny budowlane, rekreacyjne, przestrzeni publicznej, a także tereny niezbędne do rozwoju infrastruktury technicznej i komunikacyjnej miast. W każdym jednak przypadku regulacja w tym zakresie powinna cechować się racjonalnością i w wyważony sposób uwzględniać często przeciwstawne wartości.

Systemowo problematyka ochrony ilościowej gruntów rolnych i leśnych została powiązana z przepisami dotyczącymi planowania przestrzennego, czego wyrazem jest choćby przepis art. 7 ust. 1 ustawy o ochronie gruntów rolnych i leśnych, zgodnie z którym co do zasady przeznaczenia najcenniejszych z punktu widzenia produkcyjnego gruntów rolnych i leśnych na cele nierolnicze i nieleśne dokonuje się w miejscowym planie zagospodarowania przestrzennego, sporządzanym w trybie określonym w przepisach o planowaniu i zagospodarowaniu przestrzennym. ${ }^{8}$

7 A. Zieliński, Orzecznictwo sądowoadministracyjne w sprawach odrolnienia gruntów, „Zeszyty Naukowe Sądownictwa Administracyjnego" 2010, nr 5-6, s. 497. lania miejscowych planów zagospodarowania przestrzennego reguluje ustawa z 27 marca 2003 roku o planowaniu i zagospodarowaniu przestrzennym (Dz.U. Nr 80, poz. 717 z późn. zm). 
Nowelizacja ustawy o ochronie gruntów rolnych i leśnych z 19 grudnia 2008 roku ${ }^{9}$ wprowadziła poważny wyłom w tej zasadzie. Na mocy dodanego art. $5 \mathrm{~b}$ ustawy spod zakresu stosowania ustawy o ochronie gruntów rolnych i leśnych wyłączono użytki rolne położone w granicach administracyjnych miast, umożliwiając tym samym zabudowę tych terenów z pominięciem obowiązku uzyskania zgody ministra lub marszałka województwa, na zmianę przeznaczenia gruntów na cele nierolnicze, z pominięciem obowiązku uchwalania w tym celu miejscowego planu zagospodarowania, a także z pominięciem obowiązku uiszczania opłat $\mathrm{z}$ tytułu wyłączania takich gruntów z produkcji rolnej. Należy jednocześnie zwrócić uwagę, że w wyniku wspomnianej nowelizacji nie nastąpiło automatyczne przekształcenie gruntów rolnych na budowlane. Konsekwencją tej regulacji jest natomiast poddanie zasad ustalania warunków zmiany sposobu zagospodarowania gruntów rolnych położonych w granicach administracyjnych miast przede wszystkim regulacji ustawy o planowaniu i zagospodarowaniu przestrzennym. W praktyce doniosłość zmiany polega na pewnym uproszczeniu procedury uchwalania planów miejscowych dla takich terenów (odpada obowiązek uzyskania zgody ministra lub marszałka województwa na zmianę przeznaczenia gruntu rolnego na cele nierolne) oraz, co chyba ważniejsze, na umożliwieniu ustalania warunków zagospodarowania terenów dotychczas rolnych (a nieobjętych miejscowym planem zagospodarowania przestrzennego) w drodze aktu administracyjnego, jakim jest decyzja o warunkach zabudowy ${ }^{10}$. Wobec skrajnie nieefektywnej regulacji ustawy o planowaniu i zagospodarowaniu przestrzennym w zakresie sporządzania planów zagospodarowania to właśnie decyzje o warunkach zabudowy stały się współcześnie podstawowymi środkami prawnymi gospodarki przestrzenią na poziomie gmin.

Formalnie warunki wydawania decyzji o warunkach zabudowy określa art. 61 ustawy o planowaniu i zagospodarowaniu przestrzennym, zgodnie z którym ustalenie warunków zabudowy jest możliwe jedynie w przypadku spełnienia następujących warunków:

1) co najmniej jedna działka sąsiednia - dostępna z tej samej drogi publicznej - jest zabudowana w sposób pozwalający na określenie wymagań dotyczących nowej zabudowy w zakresie kontynuacji funkcji, parametrów, cech i wskaźników kształtowania zabudowy oraz zagospodarowania terenu, w tym gabarytów i formy architektonicznej obiektów budowlanych, linii zabudowy oraz intensywności wykorzystania terenu ${ }^{11}$,

2) teren ma dostęp do drogi publicznej,

Ustawa z 19 grudnia 2008 r. o zmianie ustawy o ochronie gruntów rolnych i leśnych (Dz.U. Nr 237, poz. 1657). W wyroku z 11 sierpnia 2009 roku, sygn. IV SA/Wa 697/09, sąd wyraził pogląd, że dla terenu, który wymaga zgody na zmianę przeznaczenia lub zgody takiej nie posiada, nie można ustalić warunków zabudowy dla inwestycji o przeznaczeniu innym aniżeli rolne lub leśne.

Przepisów ust. 1 pkt 1 nie stosuje się do zabudowy zagrodowej w przypadku, gdy powierzchnia gospodarstwa rolnego związanego z tą zabudową przekracza średnią powierzchnię gospodarstwa rolnego w danej gminie. 
3) istniejące lub projektowane uzbrojenie terenu jest wystarczające dla zamierzenia budowlanego,

4) teren nie wymaga uzyskania zgody na zmianę przeznaczenia gruntów rolnych i leśnych na cele nierolnicze i nieleśne albo jest objęty zgodą uzyskaną przy sporządzaniu miejscowych planów, które utraciły moc na podstawie art. 67 ustawy, o której mowa w art. 88 ust. 1,

5) decyzja jest zgodna z przepisami odrębnymi.

Nie rozwijając szerzej tego wątku, warto jedynie wskazać, że praktyka stosowania powyższego przepisu jest bardzo niejednolita, a rozstrzygnięcia administracyjne w tym przedmiocie cechuje zadziwiająca wręcz swoboda $\mathrm{w}$ jego interpretacji ${ }^{12}$. Brak precyzyjnych kryteriów, w oparciu o które wydawane są decyzje o warunkach zabudowy, w praktyce powoduje, że decyzje te zamiast aktów związanych stają się w istocie aktami polityki przestrzennej, co jak się wydaje, nie było zamiarem ustawodawcy. Należy też zwrócić uwagę, że główne kryterium wydawania decyzji o warunkach zabudowy - tzw. zasada dobrego sąsiedztwa, której głównym założeniem jest kontynuacja i powielanie rozwiązań już istniejących, nie jest i nie może być efektywnym instrumentem urbanizowania i przekształcania obszarów niezabudowanych, a raczej uzupełniania zabudowy na terenach co do zasady już zurbanizowanych i to w taki sposób, że istniejąca już na danym obszarze zabudowa pozwala na określenie wymagań dotyczących nowej zabudowy w zakresie podstawowych parametrów urbanistycznych, architektonicznych i funkcjonalnych. Nie jest to więc środek adekwatny do potrzeb związanych $\mathrm{z}$ urbanizacją terenów dotychczas wolnych od zabudowy, a do takich najczęściej zaliczane są tereny użytkowane rolniczo. Nadmienić przy tym należy, że nawet jeżeli na terenach takich występuje już zabudowa, to ma ona najczęściej charakter siedliskowy i jako taka nie może stanowić wzorca referencyjnego dla ustalania parametrów nowej zabudowy o charakterze miejskim.

Przyjmując omawianą nowelizację ustawy o ochronie gruntów rolnych i leśnych, ustawodawca rozstrzygnął konflikt dwóch wartości, uznając, że potrzeba ochrony gruntów rolnych nie powinna stać na drodze urbanizacji przestrzeni miejskiej - kierując się zapewne potrzebą doraźnego przyspieszenia i uproszczenia procedury tzw. „odralniania” gruntów, która była wskazywana jako jedna z poważniejszych barier biurokratycznych w procesie przygotowania inwestycji. Najwyraźniej jednak ustawodawca nie dostrzegł, że problem zapewnienia odpowiedniej ilości terenów inwestycyjnych ma o wiele szerszy wymiar, a jego trwałe rozwiązanie wy-

Niewatpliwie spowodowane jest to także pozostawiającym możliwość uznaniowości brzmieniem rozporządzenia Ministra Infrastruktury w sprawie sposobu ustalania wymagań dotyczących nowej zabudowy i zagospodarowania terenu w przypadku braku miejscowego planu zagospodarowania przestrzennego z dnia 26 sierpnia $2003 \mathrm{r}$. (Dz.U. Nr 164, poz. 1588), a szczególnie przepisów $\S 4$ ust. $4, \S 5$ ust. $2, \S 6$ ust. 2 , § 7 ust. 4. 
maga wprowadzenia zmian systemowych przede wszystkim w regulacjach odnoszących się do planowania przestrzennego.

Wyłączenie stosowania ustawy o ochronie gruntów rolnych i leśnych do gruntów rolnych stanowiących użytki rolne położonych w granicach administracyjnych miast jedynie formalnie i często pozornie rozwiązuje problemy właścicieli takich nieruchomości związane $\mathrm{z}$ ich nierolniczym zagospodarowaniem. Należy jednocześnie podkreślić, że omawiana zmiana ustawy może przyczynić się do pogłębienia chaosu przestrzennego już dziś cechującego wiele polskich miast, gdyż tworzy realne zagrożenie niekontrolowanymi inwestycjami na obszarach bez niezbędnego uzbrojenia w infrastrukturę techniczną i społeczną.

Przywoływane w licznych publikacjach towarzyszących nowelizacji ustawy statystyki wykazują, że tereny rolne stanowią znaczący, sięgający często kilkudziesięciu procent udział w powierzchni miast. Są to często duże i dość jednolite zespoły gruntów rolnych, w ramach których poszczególne działki posiadają cechy charakterystyczne dla działek rolnych (np. typowo rolne rozłogi granic, niski stopień uzbrojenia w infrastrukturę techniczną, infrastrukturę komunikacyjną adekwatną do produkcji rolnej, ale zupełnie nieodpowiadającą potrzebom przestrzeni miejskiej). Tereny te często nie tylko nie były dotychczas objęte miejscowymi planami zagospodarowania przestrzennego, ustalającymi w szerszym kontekście przestrzennym warunki ich nierolniczego zagospodarowania, ale wręcz przeciwnie, stanowiły formalnie przedmiot regulacji ustawy o scalaniu i wymianie gruntów promującej przekształcenia przestrzenne ukierunkowane na optymalizację warunków ich rolniczego wykorzystania. Aby tereny tego typu nie tylko formalnie, ale także faktycznie zaczęły stanowić przestrzeń inwestycyjną, należy stworzyć dogodne warunki ich zagospodarowania i wykorzystania w sposób odpowiadający nowym potrzebom. Systemowo poprawie struktury obszarowej terenów służy instytucja scalania i podziału nieruchomości uregulowana w Rozdziale 2 Działu III ustawy z 21 sierpnia 1997 roku o gospodarce nieruchomościami (u.g.n.). ${ }^{13}$ Co znamienne jednak, ustawodawca przewidział prowadzenie tego typu postępowań wyłącznie na terenach objętych miejscowymi planami zagospodarowania przestrzennego (vide art. 101 ust. 2 u.g.n.). Co więcej, to właśnie plan miejscowy - zgodnie z art. 102 u.g.n. - ma określać szczegółowe warunki scalenia i podziału nieruchomości. Uzasadnione jest twierdzenie, że scalanie jest środkiem prawnym realizacji postanowień miejscowego planu zagospodarowania przestrzennego określającego przeznaczenie i zasady zagospodarowania terenów. Scalenie ma doprowadzić zarówno do możliwości realizacji zapisów planu (realizacji norm planistycznych), jak i powstania najbardziej optymalnej struktury obszarowej, umożliwiającej wykorzystania terenów według 
ich nowego przeznaczenia określonego w planie $^{14}$. Zdaniem moim nie ulega wątpliwości, że akt indywidualny, jakim jest decyzja o warunkach zabudowy - chociażby ze względu na swój ograniczony przestrzennie zakres - nie może stanowić efektywnej podstawy do przekształcania rolniczej przestrzeni produkcyjnej w efektywną przestrzeń inwestycyjną. To nie decyzje o warunkach zabudowy obejmujące zazwyczaj pojedyncze nieruchomości, a miejscowe plany zagospodarowania przestrzennego winny być aktami określającymi możliwości nierolniczego zagospodarowania gruntów dotychczas wykorzystywanych rolniczo, przy czym plany takie winny jednocześnie wskazywać zakres i podstawowe zasady ewentualnych scaleń i podziałów, koniecznych do realizacji postanowień planu oraz regulować zasady rozbudowy infrastruktury technicznej, komunikacyjnej, melioracji, ochrony środowiska, ochrony przeciwpowodziowej i innych zagadnień, które nie mogą być skutecznie i efektywnie rozwiązywane w skali pojedynczych inwestycji.

Na marginesie warto także zwrócić uwagę, że dokonywanie zmian przeznaczenia gruntów rolnych na cele nierolnicze w planach miejscowych stanowi podstawę do naliczania opłat w postaci tzw. renty planistycznej, która stanowi (a przynajmniej może stanowić) źródło dochodu pozwalającego gminie finansować koszty rozbudowy koniecznej infrastruktury.

Dodatkowo należy także zwrócić uwagę na dość zagadkowy problem, będący prawdopodobnie wynikiem błędu legislacyjnego. Otóż zgodnie z dosłownym brzmieniem dodanego na mocy nowelizacji z 19 grudnia 2008 roku art. 5b ustawy o ochronie gruntów rolnych i leśnych, przepisów tej ustawy nie stosuje się do gruntów rolnych stanowiących użytki rolne położonych w granicach administracyjnych miast. Oznacza to, że wyłączenie to odnosi się tylko do tych gruntów rolnych, które stanowią użytki rolne ${ }^{15}$. Tymczasem, zgodnie $\mathrm{z}$ autonomiczną definicją gruntu rolnego przyjętą wyłącznie na użytek cytowanej ustawy, pojęcie to obejmuje obok gruntów sklasyfikowanych w ewidencji jako użytki rolne, także szereg innych, niebędących użytkami rolnymi rodzajów gruntów rolnych, których najwyraźniej przedmiotowe wyłączenie nie objęło.

Innym paradoksem jest także swoisty dualizm w podejściu ustawodawcy do problematyki gruntów rolnych położonych $w$ granicach administracyjnych miast. Z jednej strony, wyłączenie tych gruntów (a przynajmniej tej części z nich, które stanowią użytki rolne) z zakresu ochrony przewidzianej ustawą o ochronie gruntów rolnych i leśnych, a z drugiej strony konsekwentne utrzymywanie ograniczeń

14 E. Mzyk, (w:) G. Bieniek (red.), St. Kalus, Z. Marmaj, E. Mzyk, Ustawa o gospodarce nieruchomościami. Komentarz, Warszawa 2011, s. 497.

15 Klasyfikację użytków rolnych zawiera § 68 ust. 1 rozporządzenia Ministra Rozwoju Regionalnego i Budownictwa w sprawie ewidencji gruntów i budynków z dnia 29 marca 2001 r. (Dz.U. Nr 38, poz. 454), zgodnie z którym użytki rolne dziela się na: grunty orne $(R)$, sady $(S)$, łąki trwałe $(\measuredangle)$, pastwiska trwałe (Ps), grunty rolne zabudowane (B-R, B-Ł, B-Ps), grunty pod stawami (Wsr) i rowy (W). 
w obrocie tymi gruntami, wynikających chociażby z ustawy o kształtowaniu ustroju rolnego czy też ustawy o nabywaniu nieruchomości przez cudzoziemców. Wobec faktycznego zrównania z punktu widzenia gospodarki przestrzennej gruntów rolnych i nierolnych położonych $\mathrm{w}$ granicach administracyjnych miast za niekonsekwencję należy także uznać utrzymywanie odrębnych zasad dokonywania podziałów tych gruntów, co wynika wprost z art. 92 u.g.n.

Reasumując, wydaje się, że stan prawny powstały wskutek przyjęcia wskazanej nowelizacji ustawy o ochronie gruntów rolnych i leśnych daleki jest od wewnętrznej spójności, a dodatkowo, że rozwiązanie ułatwiające w płaszczyźnie formalnej przekształcanie gruntów rolnych w nierolne, na podstawie indywidualnych aktów administracyjnych, a więc bez konieczności (a nawet faktycznej możliwości) dokonywania zmian w strukturze przestrzennej terenów, w dłuższej perspektywie przyczyni się do pogłębienia chaosu przestrzennego i raczej utrudni, niż ułatwi prowadzenie racjonalnej działalności inwestycyjnej. W świetle powyższych uwag zasadnym wydaje się przywrócenie wymogu, aby zmiana przeznaczenia gruntów rolnych na cele nierolnicze - także w granicach miast - odbywała się na podstawie miejscowych planów zagospodarowania przestrzennego.

Wychodząc naprzeciw potrzebom upowszechniania planowania przestrzennego na obszarach miast, zasadnym wydaje się natomiast utrzymanie rozwiązania polegającego na wzmocnieniu władztwa planistycznego gminy poprzez zniesienie obowiązku uzyskiwania zgód na zmianę przeznaczenia gruntów rolnych na cele nierolnicze w toku procedury planistycznej, co niewątpliwie stanowi spore ułatwienie i znacznie skraca procedurę tworzenia planu miejscowego. 


\section{Development projects located on agricultural lands within the administrative borders of cities}

Key words: master plan, individual planning permit, good neighborhood rule

Pursuant to the new article $5 \mathrm{~b}$ of the Act on the protection of agricultural and afforested lands as amended on 19 December 2008 agricultural lands situated within the administrative borders of cities has been excluded from the scope of this Act. As a consequence, changing conditions of development of such agricultural lands is now subject to the planning and development Act only. Legislator settled the conflict of two values deciding that the need of protection of agricultural lands should not hinder the urbanization processes within the city limits. The article discusses regulatory environment created as a result of the mentioned amendment of the Act, presenting in particular potential threats that due to the actual lack of master plans and inefficient regulations promoting enactment thereof, large areas of undeveloped agricultural lands located within the city limits will be developed in accordance with individual planning permits, where the current planning and development Act does not provide for the precise criteria for issuing such planning permits in undeveloped areas that used to be a farmlands. So-called good neighborhood rule, which assumes continuation and duplication of already existing solutions seems to be inadequate tool to the needs of urbanization of undeveloped areas, to which agricultural lands are very often counted.

The author expresses opinion that the issue of providing sufficient amount of investment areas for the city development purposes has much broader dimension and may not be limited to formal status conversion. Effective transformation of agricultural production areas into investment areas requires enactment of the local master plans determining not only possibilities of non-agricultural development of particular plots but also indicating scope and basic rules for required mergers and/or divisions of land necessary for it's development, and regulating principles of development of technical and communication infrastructure (e.g. road system), drainage, environmental protection and other issues, which cannot be effectively addressed on the individual decisions level. The permanent solution of this problem would require deeper system changes particularly in development planning regulations. 